\title{
Systematical Review : Pengaruh Olahraga Sepeda terhadap Penurunan Berat Badan Pada Dewasa Muda
}

\author{
Aulia Rahma, ${ }^{1}$ Devy Claudia, ${ }^{2}$ Fajar Awalia Yulianto, ${ }^{3}$ Nurul Romadhona ${ }^{4}$ \\ ${ }^{1}$ Program Pendidikan Sarjana Kedokteran, Fakultas Kedokteran, Universitas Islam Bandung \\ ${ }^{2}$ Program Pendidikan Sarjana Kedokteran, Fakultas Kedokteran, Universitas Islam Bandung \\ ${ }^{3}$ Departemen Ilmu Kesehatan Masyarakat, Fakultas Kedokteran, Universitas Islam Bandung \\ 4Departemen Ilmu Kesehatan Masyarakat, Fakultas Kedokteran, Universitas Islam Bandung
}

\begin{abstract}
Abstrak
Kelebihan berat badan menjadi masalah kesehatan yang serius di dunia karena hal ini dapat menyebabkan sindrom metabolik hingga mengarah pada kematian. Kelebihan berat badan dapat diatasi dengan berbagai cara dengan salah satunya olahraga. Akhir-akhir ini bersepeda menjadi aktivitas olahraga yang banyak digemari di era modern. Penelitian ini bertujuan mengetahui apakah olahraga bersepeda dapat memengaruhi penurunan berat badan pada dewasa muda. Penelitian ini menggunakan metode systematical review. Database yang digunakan, yaitu Pubmed dan ProQuest dengan kata kunci "bicycling", "weight loss", "body weight change" dan "adult". PICOS pada penelitian ini, yaitu Populasi (dewasa muda), Intervensi (olahraga sepeda), Outcome (penurunan berat badan), Study (Randomized Control Trial dan Clinical trial). Jumlah jurnal yang didapat dari dua database yaitu 79 jurnal, kemudian dilakukan screening hingga didapatkan 3 jurnal. Jurnal ini diambil dari tahun 2010-2020. Hasil penelitian ini menunjukkan dua artikel dari tiga artikel yang diperoleh bahwa olahraga bersepeda berpengaruh terhadap penurunan berat badan. Durasi bersepeda selama 30-55 menit dengan frekuensi tiga sampai lima kali dalam seminggu dengan intensitas sedang dan pengendalian asupan makanan dapat menurunkan berat badan.
\end{abstract}

Kata kunci: Bersepeda, kelebihan berat badan, penurunan berat badan

\section{The Effect of Bicycle Exercise on Weight Loss in Young Adults: Systematical Review}

\begin{abstract}
Being overweight is a serious health problem in the world because it can lead to metabolic syndrome leading to death. Being overweight can be overcome in various ways with one of them is exercise. Lately cycling has become a much-loved sporting activity in the modern era. The study aims to find out if cycling can affect weight loss in young adults. This research uses systematical review method. Database used, namely Pubmed and ProQuest with keywords "bicycling", "weight loss", "body weight change" and "adult". PICOS in this study are Population (young adult), Intervention (bicycle sports), Outcome (weight loss), Study (Randomized Control Trial and Clinical trial). The number of journals obtained from two databases, namely 79 journals, was then screened until 3 journals were obtained. This journal was taken from 2010-2020. The results of this study showed two articles from three articles obtained that cycling sports have an effect on weight loss. Cycling duration for 30-55 minutes with a frequency of three to five times a week with moderate intensity and the control of food intake can lose weight.
\end{abstract}

Keywords: Bicycling, overweight, weight loss

Received: 8 ...; Revised: ...; Accepted: ...; Published: ...

Koresponden: Aulia Rahma. Prodi Pendidikan Sarjana Kedokteran, Fakultas Kedokteran, Universitas Islam Bandung, Jalan Tamansari No. 22, 40116, Kota Bandung, provinsi Jawa Barat, Hp: 085966433957 Email: auliarahmafkunisba@gmail.com 


\section{Pendahuluan}

Kelebihan berat badan menjadi masalah yang serius terhadap kesehatan global di dunia karena hal ini dapat menyebabkan sindrom metabolik hingga mengarah pada kematian. ${ }^{1}$ Kelebihan berat badan perlu diperhatikan karena mempunyai risiko morbiditas tinggi yang akan mempengaruhi peningkatan mortalitas. $^{2}$ Kelebihan berat badan merujuk pada overweight dan obesitas. ${ }^{3}$

Pada tahun 2016 berdasarkan World Health Organization (WHO), prevalensi obesitas di dunia sebanyak lebih dari 1,9 miliar orang dewasa dengan usia 18 tahun ke atas dengan 39\% laki-laki dan 40\% perempuan mengalami kelebihan berat badan. Pada jumlah tersebut, lebih dari 650 juta orang dewasa dengan $11 \%$ pria dan $15 \%$ wanita mengalami obesitas. ${ }^{1}$

Menurut Riset Kesehatan Dasar (RISKESDAS), pada tahun 2013 di Indonesia, prevalensi obesitas pada orang dewasa mencapai $19,7 \%$ laki-laki dan $32,9 \%$ perempuan. Pada tahun 2010, prevalensi obesitas pada orang dewasa $13,9 \%$ laki-laki dan $15,5 \%$ perempuan. Hal ini menunjukkan adanya peningkatan dari tahun 2010 ke 2013 dan prevalensi perempuan lebih banyak daripada laki-laki. ${ }^{1}$ Prevalensi obesitas diperkirakan akan terus meningkat dikarenakan perubahan pola hidup masyarakat Indonesia. ${ }^{2}$ Hal ini disebabkan karena perubahan pola hidup terutama pola makan yang merujuk pada pola makan tinggi energi, misalnya makanan siap saji yang banyak tersedia di perkotaan sehingga meningkatkan risiko obesitas. ${ }^{1}$

Obesitas disebabkan karena ketidakseimbangan antara kalori yang dikonsumsi dan kalori yang dikeluarkan. ${ }^{4}$ Obesitas dapat menyebabkan berbagai penyakit terutama penyakit cardiovascular, diabetes melitus, kanker, dan penyakit lain seperti hipertensi, kolesterol tinggi, gangguan muskuloskeletal, dan kesehatan mental yang buruk..$^{5-6}$ Banyak faktor yang dapat menyebabkan terjadinya obesitas, beberapa di antaranya seperti faktor lingkungan, genetik, dan psikis. $^{7}$

Masalah obesitas ini bisa diatasi dengan konsumsi makanan sehat serta perbanyak air putih, istirahat yang cukup, dan olahraga. ${ }^{6}$ Seperti di dalam Qs. Al-A'raf ayat 31 mengenai konsumsi makanan, Allah SWT berfirman :"Wahai anak cucu Adam! Pakailah pakaianmu yang bagus pada setiap memasuki masjid, makan dan minumlah, tetapi jangan berlebihan. Sungguh, Allah tidak menyukai orang yang berlebih-lebihan." Seperti dalam Qs. Al-Qashahs ayat 73 tentang istirahat yang cukup, Allah SWT berfirman : "Dan karena rahmatNya, dia jadikan untukmu malam dan siang, supaya kamu beristirahat pada malam itu dan supaya kamu mencari sebagian dari karuniaNya (pada siang hari) dan supaya kamu bersyukur". Seperti di dalam hadist riwayat Ath-Thabarani dan Az-Zabidi berikatan dengan olahraga, ia berkata "Rasulullah itu berdada lebar. Antara perut dan dada berukuran sama".

Manfaat olahraga adalah menurunkan risiko penyakit degeneratif, meningkatkan kapasitas jantung, mencegah hipertensi, memperbaiki lipid darah, mencegah osteoporosis, menjaga fleksibilitas otot dan sendi, serta meningkatkan sistem kekebalan tubuh, mengendalikan stres, dan mengurangi kecemasan serta depresi. $^{8}$
Di Indonesia dari kurun waktu 2003, 2006, dan 2009 keinginan penduduk dalam melakukan olahraga terus menurun, yaitu dari $25,4 \%$ pada tahun 2003, turun menjadi $23,2 \%$ pada tahun 2006, dan terakhir turun menjadi 21,8\% pada tahun 2009. ${ }^{9}$ Kemudahan dan pesatnya Ilmu Pengetahuan dan Teknologi (IPTEK) mengakibatkan kebanyakan orang malas dalam melakukan olahraga. Olahraga sudah dilupakan oleh sebagian individu karena kesibukan. Oleh karena itu, olahraga sederhana dapat dijadikan pilihan dalam menjaga kesehatan, namun tidak menyita banyak waktu seperti jalan cepat, senam, lari, dan bersepeda. ${ }^{6}$

Akhir-akhir ini bersepeda menjadi aktivitas olahraga yang banyak digemari di era modern. Olahraga sepeda selain banyak digemari juga memiliki efek lainnya, seperti pada penurunan berat badan. ${ }^{10}$ Tujuan dari penelitian ini adalah melihat pengaruh dari olahraga sepeda terhadap penurunan berat badan pada dewasa muda.

\section{Metode}

Jenis penelitian yang digunakan adalah systematical review. Dilakukan review pada artikel-artikel penelitian yang terpilih dengan beberapa langkah sebagai berikut:

1. Pencarian data mengacu sumber database seperti PubMed dengan kata kunci yaitu "bicycling" $A N D$ "weight loss"OR"weight loss change"AND "adult" \& ProQuest dengan kata kunci "bicycling"AND "adult" AND "weight loss".

2. Skrining Data. Skrining adalah penyaringan atau pemilihan data (artikel penelitian) yang bertujuan memilih masalah penelitian yang sesuai dengan topik atau judul, abstrak, dan kata kunci yang diteliti. Membuang artikel atau penelitian yang duplikasi. Tahun artikel pada penelitian ini diambil dalam rentan waktu 10 tahun yaitu 2010-2020.

3. Pencarian artikel sesuai dengan kriteria PICOS :

- Population : Dewasa muda

- Intervention : Olahraga sepeda

- Comparation : Perbandingan yang dilakukan sebagai kontrol antara kelompok yang diberi intervensi berupa bersepeda dan kelompok yang tidak diberikan intervensi atau diberikan intervensi lain.

- Outcome : Penurunan berat badan

- Study : Randomized Control Trial (RCT) dan Clinical trial

4. - Kriteria inklusi pada penelitian ini :

a) Artikel yang digunakan yang telah diterbitkan oleh jurnal internasional yang berkaitan dengan permasalahan penelitian.

b) Database yang digunakan pada penelitian ini adalah PubMed dengan kata kunci yaitu "bicycling", "weight loss", "adult", dan "weight loss change" \& ProQuest dengan kata kunci "bicycling", "adult", dan "weight loss" (sesuai PICOS).

c) Artikel yang dipergunakan dalam penelitian diterbitkan dalam rentang waktu 10 tahun dari 2010-2020. 
d) Tipe artikel yang dipergunakan dalam penelitian berupa research articles seperti randomized control trial (RCT) atau pre dan post clinical trial.

e) Artikel penelitian yang dapat diakses secara penuh (full text).

f) Artikel berbahasa Inggris dan berbahasa Indonesia.

-Kriteria eksklusi pada penelitian ini :

a) Ketidaksesuaian antara judul artikel dan abstrak.

b) Artikel lengkap yang tidak dapat diakses.

5. Perbedaan pendapat antara peneliti 1 dan 2 (Devy Claudia) akan diselesaikan oleh peneliti ke 3 (pembimbing I).

6. Dilakukan telaah kritis terhadap artikel yang telah disetujui. Hasil telaah kritis dengan metode CONSORT berupa validitas dari penelitian.

7. Penelitian yang valid diekstraksi hasil penelitiannya.

8. Kesimpulan akhir dari penelitian berupa level of evidence menggunakan kriteria Evidence Base Medicine (EBM) oxford.
Tabel 1 Level of evidence ${ }^{11}$

\begin{tabular}{|c|c|}
\hline Level & Type of evidence \\
\hline $1 \mathrm{a}$ & $\begin{array}{l}\text { Systematical review (dengan homogenitas) dari } \\
\text { RCTs }\end{array}$ \\
\hline $1 \mathrm{~b}$ & $\begin{array}{l}\text { Individual RCT (dengan interval kepercayaan } \\
\text { yang sempit) }\end{array}$ \\
\hline $1 \mathrm{c}$ & All-or-none study \\
\hline $2 \mathrm{a}$ & $\begin{array}{l}\text { Systematical review (dengan homogenitas) dari } \\
\text { studi kohort }\end{array}$ \\
\hline $2 b$ & $\begin{array}{l}\text { Individual studi kohort, termasuk RCTs kualitas } \\
\text { rendah (contoh < } 80 \% \text { follow up) }\end{array}$ \\
\hline $2 \mathrm{c}$ & "luaran" penelitian; studi ekologi \\
\hline 3a & $\begin{array}{l}\text { Systematical review (dengan hemogenitas) dari } \\
\text { studi case-control }\end{array}$ \\
\hline $3 b$ & Individual studi case control \\
\hline 4 & $\begin{array}{l}\text { Case series (kualitas kohort dan studi case } \\
\text { control yang buruk) }\end{array}$ \\
\hline 5 & $\begin{array}{l}\text { Pendapat ahli tanpa penilaian kritis eksplisit } \\
\text { atau berdasarkan fisiologi, kedudukan } \\
\text { penelitian, atau "prinsip utama" }\end{array}$ \\
\hline
\end{tabular}

\section{Hasil}

\section{Gambar 1 Diagram Prisma}

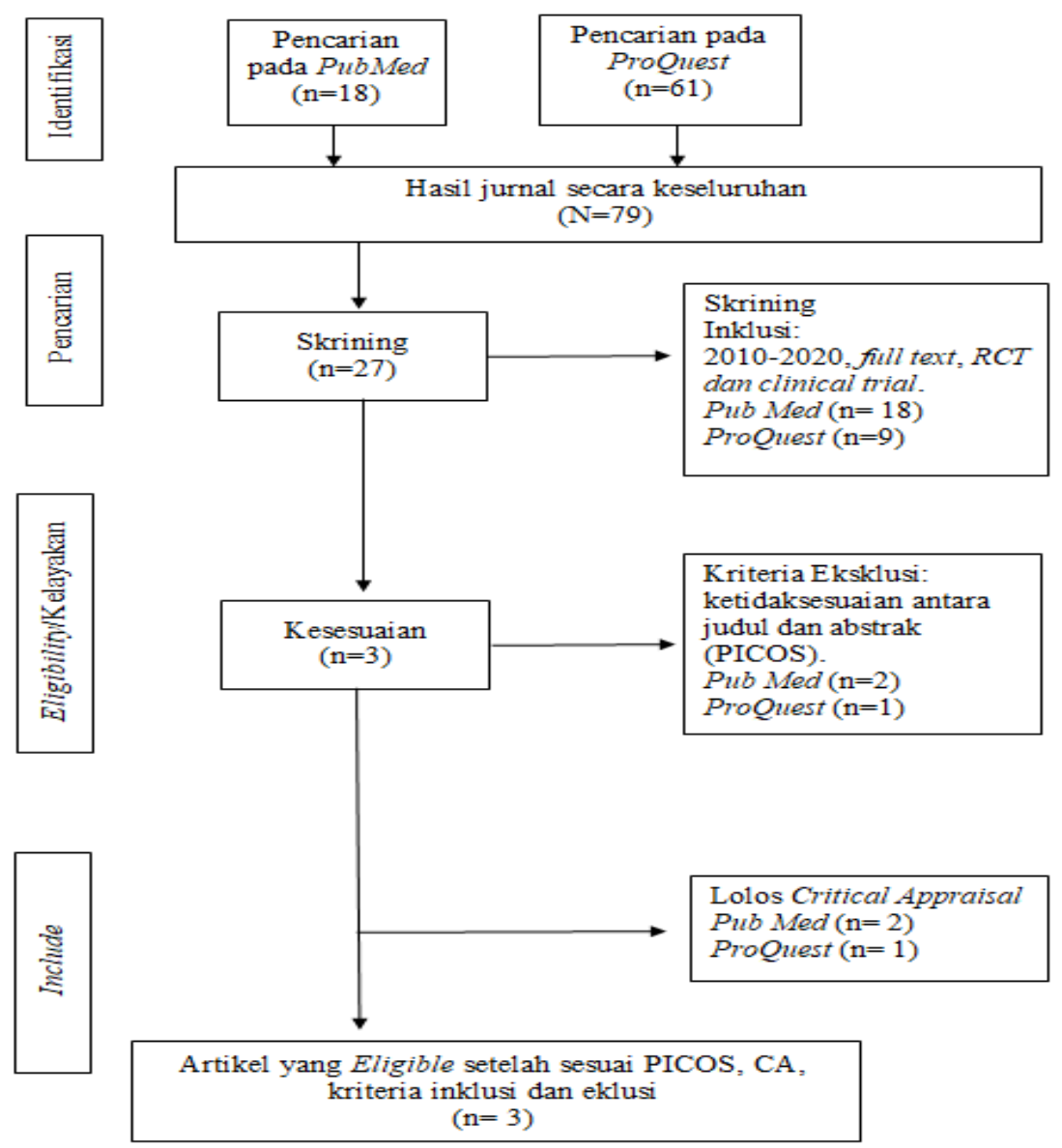


Tabel 2 Hasil Systematical Review Pengaruh Olahraga Sepeda terhadap Penurunan Berat Badan pada Dewasa Muda

\begin{tabular}{|c|c|c|c|c|c|}
\hline Judul/ Peneliti & Tujuan & $\begin{array}{c}\text { Jumlah } \\
\text { Responden }\end{array}$ & $\begin{array}{c}\text { Metode } \\
\text { Pengukuran }\end{array}$ & Teknik Analisis & Hasil \\
\hline $\begin{array}{l}\text { Eccentric cycling } \\
\text { is more efficient } \\
\text { in reducing } \\
\text { fat mass than } \\
\text { concentric } \\
\text { cycling in } \\
\text { adolescents with } \\
\text { obesity. } \\
\text { Valerie, } \mathrm{dkk}^{12} \\
2019 \\
\text { Perancis }\end{array}$ & $\begin{array}{l}\text { Membandingkan } \\
\text { penggunaan } \\
\text { sepeda } \\
\text { esentrik dan } \\
\text { konsentrik untuk } \\
\text { menurunkan } \\
\text { massa lemak. }\end{array}$ & $\begin{array}{l}\text { Dua puluh tiga } \\
\text { remaja yang } \\
\text { mengalami } \\
\text { obesitas } \\
\text { dengan usia } \\
\text { 12-16 tahun, }\end{array}$ & $\begin{array}{l}\text { Intervensi terdiri } \\
\text { dari program } \\
\text { bersepeda selama } \\
12 \text { minggu dengan } \\
36 \text { kali latihan } \\
\text { ergometer, } \\
\text { Dilakukan } \\
\text { pengukuran } \\
\text { antropometri, } \\
\text { pengukuran } \\
\text { komposisi tubuh, } \\
\text { sampel darah, tes } \\
\text { kekuatan isometrik } \\
\text { dan isokinetik } \\
\text { sebelum latihan } \\
\text { ataupun setelah } \\
\text { melakukan latihan. } \\
\text { pengendalian asupan } \\
\text { makanan dengan } \\
\text { diet normo-kalori, }\end{array}$ & $\begin{array}{l}\text { Teknik analisis } \\
\text { pada penelitian } \\
\text { ini menggunakan } \\
\text { chi-squared atau uji } \\
\text { Fisher. Hubungan } \\
\text { antara variabel } \\
\text { kuantitatif dengan } \\
\text { menghitung } \\
\text { koefisien korelasi } \\
\text { menggunakan } \\
\text { Pearson atau } \\
\text { Spearman. }\end{array}$ & $\begin{array}{l}\text { Penurunan } \\
\text { massa lemak } \\
\text { yang signifikan } \\
\text { setelah bersepeda } \\
\text { dibandingkan } \\
\text { sebelum bersepeda. } \\
\text { Indeks massa } \\
\text { tubuh mengalami } \\
\text { penurunan. Sepeda } \\
\text { eksentrik lebih } \\
\text { unggul dalam } \\
\text { mengurangi } \\
\text { massa lemak dan } \\
\text { penurunan berat } \\
\text { badan dibandingkan } \\
\text { sepeda konsentrik. }\end{array}$ \\
\hline $\begin{array}{l}\text { Biking for } \\
\text { Health: Results } \\
\text { of a Pilot } \\
\text { Randomized } \\
\text { Controlled Trial } \\
\text { Examining } \\
\text { the Impact of } \\
\text { a Bicycling } \\
\text { Intervention on } \\
\text { Lower-Income } \\
\text { Adults. } \\
\text { Rebecca,dkk }{ }^{13} \\
2017 \\
\text { Amerika Serikat }\end{array}$ & $\begin{array}{l}\text { Menilai apakah } \\
\text { ada hambatan } \\
\text { dalam bersepeda } \\
\text { (perilaku) pada } \\
\text { partisipan } \\
\text { penelitian ini } \\
\text { (orang dewasa } \\
\text { yang tidak aktif, } \\
\text { berpenghasilan } \\
\text { rendah, dan } \\
\text { mempunyain } \\
\text { berat badan } \\
\text { berlebih).. }\end{array}$ & $\begin{array}{l}\text { \%2 mendaftar } \\
49 \text { orang } \\
\text { memenuhi } \\
\text { syarat untuk } \\
\text { berpartisipasi } \\
\text { kemudian } \\
\text { diacak, dengan } \\
\text { 20 ditugaskan } \\
\text { ke kelompok } \\
\text { kontrol dan } \\
29 \text { untuk } \\
\text { intervensi } \\
\text { bersepeda. } \\
\text { Total akhir } \\
\text { responden } \\
\text { adalah } 26 \\
\text { orang. }\end{array}$ & $\begin{array}{l}\text { Uji coba acak } \\
\text { terkontrol } \\
\text { nonblinded. Usia } \\
\text { peserta } 18-69 \text { tahun. } \\
\text { Peserta akan diberi } \\
\text { intervensi bersepeda } \\
\text { selama } 12 \text { minggu } \\
\text { selama } 20 \text { menit } \\
\text { atau lebih. Dinilai } \\
\text { dari ukuran hasil } \\
\text { termasuk sikap } \\
\text { terkait bersepeda, } \\
\text { aktivitas fisik, } \\
\text { kebugaran yang } \\
\text { diukur dengan tes } \\
\text { langkah } 6 \text { menit, } \\
\text { dan data biometrik } \\
\text { dikumpulkan pada } \\
\text { awal, } 12 \text { minggu, dan } \\
\text { 20 minggu. }\end{array}$ & $\begin{array}{l}\text { t- test untuk } \\
\text { variabel kontinu, uji } \\
\text { chi-square, Fisher } \\
\text { untuk proporsi dan } \\
\text { variabel kategori } \\
\text { serta uji Wilcoxon } \\
\text { rank-sum untuk } \\
\text { variabel ordinal. } \\
\text { Dua sampel } \\
\text { berpasangan } t \text { - test } \\
\text { digunakan untuk } \\
\text { mengidentifikasi } \\
\text { perubahan }\end{array}$ & $\begin{array}{l}\text { Terdapat } \\
\text { penurunan berat } \\
\text { badan, namun } \\
\text { tidak berpengaruh } \\
\text { yang terlihat pada } \\
\text { minggu ke } 12 \text { dan } \\
\text { minggu ke } 20 \text {. }\end{array}$ \\
\hline $\begin{array}{l}\text { Effects of an } \\
\text { Indoor Cycling } \\
\text { Program on } \\
\text { Cardiometabolic } \\
\text { Factors in } \\
\text { Women with } \\
\text { Obesity vs. } \\
\text { Normal Body } \\
\text { Weight. } \\
\text { Marzena,dkk }{ }^{14} \\
\text { 2O20 } \\
\text { Polandia }\end{array}$ & $\begin{array}{l}\text { Melihat efek } \\
\text { olahraga } \\
\text { bersepeda di } \\
\text { dalam ruangan } \\
\text { (Indoor } \\
\text { Cycling) untuk } \\
\text { mengurangi } \\
\text { faktor risiko } \\
\text { kardiometabolik } \\
\text { dan mengurangi } \\
\text { berat badan. }\end{array}$ & $\begin{array}{l}\text { Kelompok } \\
\text { wanita obesitas } \\
\text { terdiri dari } 18 \\
\text { orang. }\end{array}$ & $\begin{array}{l}\text { Membandingkan } \\
\text { efek program latihan } \\
\text { fisik selama } 3 \text { bulan } \\
\text { pada wanita obesitas } \\
\text { sebanyak } 18 \text { orang } \\
\text { dengan wanita } \\
\text { dengan berat badan } \\
\text { normal sebanyak } 8 \\
\text { orang. Intervensi } \\
\text { selama tiga bulan } \\
\text { terdiri dari program } \\
\text { latihan fisik yaitu } \\
\text { tiga sesi bersepeda di } \\
\text { dalam ruangan per } \\
\text { minggu. Totalnya } \\
\text { adalah } 36 \text { sesi } \\
\text { latihan. }\end{array}$ & $\begin{array}{l}\text { Tes Mann-Whitney } \\
U \text { dan Tes Wilcoxon } \\
\text { rank-sum }\end{array}$ & $\begin{array}{l}\text { Hasil penelitian } \\
\text { ini menunjukkan } \\
\text { bahwa bersepeda } \\
\text { selama } 12 \text { minggu } \\
\text { di dalam ruangan } \\
\text { secara teratur } \\
\text { merupakan cara } \\
\text { yang ampuh untuk } \\
\text { menurunkan berat } \\
\text { badan pada wanita } \\
\text { dengan berat } \\
\text { badan normal dan } \\
\text { obesitas. }\end{array}$ \\
\hline
\end{tabular}


Tabel 3 Teknis bersepeda dan perubahan berat badan

Judul Penelitian

Eccentric cycling is more efficient in reducing fat mass than concentric cycling in adolescents with obesity.

(Valerie,dkk) ${ }^{12}$

Biking for Health: Results of a Pilot Randomized Controlled Trial Examining the Impact of a Bicycling Intervention on LowerIncome Adults. (Rebecca,dkk) ${ }^{13}$

Teknis bersepeda
Perubahan berat badan
Effects of an Indoor Delapan belas orang wanita obesitas dan delapan Cycling Program on orang wanita dengan berat badan normal yang Cardiometabolic Factors sesuai kriteria akan diberi intervensi bersepeda in Women with Obesity vs. di dalam ruangan selama tiga bulan dalam waktu Normal Body Weight. (Marzena,dkk) ${ }^{14}$

55 menit.
Dua puluh tiga remaja obesitas usia 12-16 tahun dengan 11 laki-laki dan 12 perempuan diberi intervensi sepeda eksentrik dan konsentrik selama 12 minggu dengan 36 sesi latihan yang setiap minggunya terdiri dari tiga sesi dengan waktu 30-55 menit.

Penelitian dilakukan di dua tempat yaitu SSNC dan $16^{\text {th }}$ St. Setelah layak, peserta akan dimasukan ke dalam kelompok kontrol dan intervensi. Setelah itu, peserta akan diberi intervensi bersepeda selama 12 minggu selama 20 menit atau lebih.

Perubahan berat badan terlihat dari adanya penurunan massa lemak dan indeks massa tubuh. Dapat dilihat dari berat badan pada sepeda eksentrik sebelum bersepeda yaitu $82,8 \mathrm{~kg}$ dan setelah bersepeda yaitu $78,8 \mathrm{~kg}$ (4,0 kg).

Berat badan yang menurun namun tidak berpengaruh pada kelompok kontrol, yaitu dari IMT 38,2 sebelum bersepeda menjadi 36,5 setelah bersepeda selama 12 minggu $(1,7)$. Perubahan berat badan pada kelompok intervensi, yaitu dari IMT 35,4 sebelum bersepeda menjadi 34,8 setelah bersepeda selama 12 minggu $(0,6)$.

Perubahan berat badan terlihat pada wanita obesitas sebelum latihan, yaitu $95,2 \mathrm{~kg}$ dan setelah bersepeda, yaitu $92,9 \mathrm{~kg}(2,3 \mathrm{~kg})$.

Tabel 4 Hasil validitas menggunakan metode CONSORT dan EBM Oxford

\begin{tabular}{|c|c|c|c|c|c|c|}
\hline Judul Penelitian & $\begin{array}{c}\text { Metode } \\
\text { penelitian }\end{array}$ & $\begin{array}{l}\text { Validitas } \\
\text { internal }\end{array}$ & Randomisasi & $\begin{array}{c}\text { Diperlakukan } \\
\text { sama }\end{array}$ & Blind & Kesimpulan \\
\hline $\begin{array}{l}\text { Eccentric cycling } \\
\text { is more efficient in } \\
\text { reducing fat mass than } \\
\text { concentric cycling } \\
\text { in adolescents with } \\
\text { obesity. } \\
\text { (Valerie,dkk) }^{12}\end{array}$ & Clinical trial & $\begin{array}{l}\text { PICOS } \\
\text { sesuai }\end{array}$ & $\begin{array}{l}\text { Peserta akan } \\
\text { diacak dan } \\
\text { ditetapkan apakah } \\
\text { menggunakan } \\
\text { sepeda eksentrik } \\
\text { atau konsentrik. }\end{array}$ & $\begin{array}{l}\text { Responden } \\
\text { diperlakukan } \\
\text { sama }\end{array}$ & $\begin{array}{l}\text { Tidak, } \\
\text { dikarenakan } \\
\text { intervensi } \\
\text { berupa } \\
\text { perlakuan }\end{array}$ & Valid \\
\hline $\begin{array}{l}\text { Biking for Health: } \\
\text { Results of a Pilot } \\
\text { Randomized Controlled } \\
\text { Trial Examining the } \\
\text { Impact of a Bicycling } \\
\text { Intervention on Lower- } \\
\text { Income Adults. } \\
\text { (Rebecca,dkk) }\end{array}$ & $\begin{array}{l}\text { Randomized } \\
\text { control trial }\end{array}$ & $\begin{array}{l}\text { PICOS } \\
\text { sesuai }\end{array}$ & $\begin{array}{l}\text { Empat puluh } \\
\text { sembilan orang } \\
\text { memenuhi syarat } \\
\text { untuk berpartisipasi } \\
\text { kemudian } \\
\text { diacak, dengan } \\
\text { 20 ditugaskan } \\
\text { ke kelompok } \\
\text { kontrol dan } 29 \\
\text { untuk intervensi } \\
\text { bersepeda }\end{array}$ & $\begin{array}{l}\text { Responden } \\
\text { diperlakukan } \\
\text { sama }\end{array}$ & $\begin{array}{l}\text { Tidak, } \\
\text { karena uji } \\
\text { coba yang } \\
\text { dilakukan di } \\
\text { dua tempat } \\
\text { (SSNC dan } \\
16^{\text {th }} \text { St) } \\
\text { secara acak } \\
\text { terkontrol } \\
\text { nonblinded. }\end{array}$ & Valid \\
\hline $\begin{array}{l}\text { Effects of an Indoor } \\
\text { Cycling Program } \\
\text { on Cardiometabolic } \\
\text { Factors in Women with } \\
\text { Obesity vs. Normal } \\
\text { Body Weight. } \\
\text { (Marzena,dkk) }\end{array}$ & Clinical trial & $\begin{array}{l}\text { PICOS } \\
\text { sesuai }\end{array}$ & $\begin{array}{l}\text { Responden tidak } \\
\text { diacak terlebih } \\
\text { dahulu }\end{array}$ & $\begin{array}{l}\text { Responden } \\
\text { diperlakukan } \\
\text { sama }\end{array}$ & $\begin{array}{l}\text { Tidak, } \\
\text { dikarenakan } \\
\text { intervensi } \\
\text { berupa } \\
\text { perlakuan }\end{array}$ & Valid \\
\hline
\end{tabular}

Hasil penelitian berisi uraian atikel penelitian yang telah dilakukan review berdasarkan kriteria yang telah ditentukan sebelumnya pada kriteria inklusi dan eksklusi, terpilihlah tiga artikel yang dianalisis pada systematical literature review ini. Dari artikel yang dipilih, dua artikel merupakan penelitian clinical trial dan satu artikel merupakan randomized control trial.
Penelitian ini berasal dari Perancis, Amerika, dan Polandia. Penelitian ini menggunakan sampel dewasa muda, sampel remaja, dan dewasa dikarenakan keterbatasan usia dalam artikel penelitian. Dua artikel penelitian menggunakan sampel yang terdiri dari lakilaki dan perempuan, sedangkan satu artikel penelitian menggunakan sampel berjenis kelamin perempuan. 
Dari ketiga penelitian, olahraga bersepeda dilakukan selama 12 minggu dengan intensitas waktu dalam sekali bersepeda, yaitu 30-55 menit, dengan dilakukan pengukuran antropometri serta komposisi tubuh sebelum dan sesudah melakukan olahraga sepeda agar dapat dilihat perubahan dari massa tubuh responden. Dari ketiga artikel, masing-masing mempunyai level of evidence sesuai dengan kriteria EBM oxford, yaitu satu artikel yang memiliki level of evidence $1 \mathrm{~b}$ dan dua artikel yang memiliki level of evidence $2 \mathrm{~b}$.

Hasil penelitian yang menyatakan terdapat pengaruh bersepeda terhadap penurunan berat badan ditemukan pada kedua penelitian yang dianalisis pada systematical literature review ini. Hasil penelitian Valerie, dkk menyatakan bahwa berolahraga sepeda eksentrik dapat menurukan massa lemak seluruh tubuh secara signifikan sebanyak -10\% untuk sepeda eksentrik dan $-4,2 \%$ untuk sepeda konsentrik. ${ }^{12}$ Rebecca, dkk menyatakan hasil dari penelitiannya, yaitu terdapat penurunan pengukuran biometrik pada BMI, namun tidak berpengaruh. ${ }^{13}$ Hasil dari penelitian Marzena, dkk menyimpulkan bahwa dengan bersepeda wanita obesitas lebih banyak mengalami penurunan massa tubuh yang signifikan dibandingkan dengan wanita yang berat badannya normal. ${ }^{14}$

\section{Pembahasan Penelitian}

Penelitian mengenai pengaruh olahraga sepeda terhadap penurunan berat badan sesuai dengan dua artikel yang telah dilakukan review bersadarkan kriteria elegible atau kelayakan dan pada satu artikel tidak terdapat pengaruh. Pembahasan ini akan merujuk pada kriteria hills.

Pertama, yaitu strength of asosiation. Strength of asosiation adalah ketika semakin besar hubungan antar paparan dan penyakit, semakin besar kemungkinan menjadi penyebab. ${ }^{15}$ Pada kedua penelitian yaitu artikel kesatu dan ketiga menyatakan bahwa bersepeda dapat menurunkan berat badan dengan durasi selama 30-55 menit dan frekuensi tiga sampai lima kali dalam seminggu. ${ }^{12-14}$ Terdapat hubungan yang terkait antara variabel terikat, yaitu berat badan dan variabel bebas, yaitu olahraga sepeda, dikarenakan olahraga bersepeda mempengaruhi kausalitas dalam menurunkan berat badan. ${ }^{12-14}$

Kedua, yaitu konsistensi. Kriteria konsistensi ditegakkan ketika studi epidemiologi multipel yang menggunakan berbagai macam lokasi, populasi, dan metode menunjukkan hubungan atau hasil yang konsisten antara dua variabel. ${ }^{15}$ Penelitian ini dapat dinilai konsisten pada kedua artikel yaitu artikel kesatu dan ketiga karena memiliki hasil yang konsisten, yaitu terdapat penurunan berat badan setelah dilakukan intervensi bersepeda. ${ }^{12-14}$

Ketiga, yaitu spesifitas. Spesifitas adalah hubungan kausal yang spesifik, dimana paparan hanya menyebabkan satu penyakit. ${ }^{15}$ Penelitian ini tidak memenuhi poin spesifitas karena dampak bersepeda tidak hanya menurunkan berat badan. ${ }^{12-14}$

Keempat, yaitu temporalitas. Temporalitas adalah kesimpulan kausal. ${ }^{15}$ Penelitian ini memenuhi poin temporalitas karena adanya hubungan antara bersepeda dengan penurunan berat badan. ${ }^{12-14}$

Kelima, yaitu biologic gradient. Biologic gradient adalah adanya hubungan dosis-respon, yaitu hubungan antara paparan dan efek. ${ }^{15}$ Pada penelitian ini, bersepeda selama 30-55 menit dalam waktu tiga sampai lima kali (dosis) berpengaruh dalam penurunan berat badan (respon)..$^{12-14}$

Keenam dan ketujuh, yaitu plausibility dan koherensi. Plausability adalah adanya hubungan konsisten dengan pengetahuan terkini mengenai penyebab dan mekanisme penyakit, sedangkan koherensi dipandang mirip dengan plausabilty karena sebab-akibat yang dibuat. ${ }^{15}$

Koherensi dan plausibility dalam penelitian ini, yaitu bersepeda dapat menurunkan berat badan dengan cara meningkatkan resistensi insulin sehingga dapat menurunkan lingkar pinggang, massa lemak dalam tubuh, dan meningkatkan massa otot. ${ }^{12}$ Pada penelitian yang tercantum di dalam ketiga artikel, menyatakan adanya hubungan kausa, yaitu olahraga sepeda yang dilakukan dengan intensitas yang baik maka akan terjadi penurunan berat badan. ${ }^{12-14}$

Kedelapan, yaitu eksperimen. Eksperimen adalah suatu bukti yang diambil dari eksperimen manipulasi dalam risiko penyakit yang menurun setelah intervensi. ${ }^{15}$ Dalam penelitian ini untuk risiko berat badan terbukti menurun setelah dilakukannya intervensi bersepeda pada artikel kesatu dan ketiga. 12-14

Kesembilan,yaituanalogi.Analogidiinterpretasikan ketika suatu agen, penyebabnya dapat diketahui. ${ }^{15}$ Dalam penelitian ini, olahraga bersepeda belum tentu menjadi agen penyebab penurunan berat badan, karena faktor penyebab penurunan berat badan yang lain, yaitu asupan makanan tidak dikontrol pada kedua artikel. $^{12}$

\section{Keterbatasan}

Keterbatasan dari penelitian systematical review ini adalah pada artikel penelitian mengenai sepeda jauh lebih sedikit dibandingkan artikel pada olahraga yang mudah seperti jalan kaki.

\section{Simpulan}

Simpulan pada penelitian ini adalah olahraga bersepeda dapat menurunkan berat badan dilihat dari dua artikel, namun tidak berpengaruh pada satu artikel.

\section{Saran}

Saran pada penelitian ini adalah sebagai berikut.

1. Bagi Fakultas Kedokteran Universitas Islam Bandung

Dengan adanya masalah ini, diharapkan Fakultas Kedokteran Universitas Islam Bandung dapat mengupayakan program promotif dan preventif masalah kelebihan berat badan pada sumber daya manusia di Fakultas Kedokteran Universitas Islam Bandung. 
2. Bagi peneliti selanjutnya

Hasil penelitian ini dapat dijadikan bahan untuk penelitian selanjutnya dengan menggunakan systematic literatur review.

\section{Ucapan Terimakasih}

Penulis mengucapkan terima kasih kepada Dekan Fakultas Kedokteran Universitas Islam Bandung dan semua pihak yang terlibat dalam penelitian ini.

\section{Konflik Kepentingan}

Peneliti tidak memiliki konflik kepentingan dan tidak mendapat pendanaan pada penelitian ini.

\section{Daftar Pustaka}

1. Witono SK, Nugraha GI, Permana H, Adi S. Profil Massa Lemak dan Lingkar Pinggang Dewasa Obes dan Nonobes di Cirebon. Glob Med Heal Commun. 2018;6(1):7-11.

2. Septiana P, Irwanto I. Hubungan Durasi Tidur dengan Kejadian Obesitas pada Anak Usia 3-8 Tahun. Glob Med Heal Commun [Internet]. 2018;6(1):63-7. Tersedia dari: https:// ejournal.unisba.ac.id/index.php/gmhc/ article/view/26 96

3. Sung H, Siegel RL, Torre LA, Pearson-Stuttard $\mathrm{J}$, Islami F, Fedewa SA, et al. Global patterns in excess body weight and the associated cancer burden. CA Cancer J Clin. 2018;88-112.

4. Yunitasari AR, Sinaga T, Nurdiani R. Asupan Gizi, Aktivitas Fisik, Pengetahuan Gizi, Status Gizi Dan Kebugaran Jasmani Guru Olahraga Sekolah Dasar [Nutritient Intake, Physical Activity, Nutrition Knowledge, Nutritional Status, and Physical Fitness of Elementary School Sport Teacher]. Media Gizi Indones. 2019;14(2):197.

5. Engin AB, Engin A. Obesity and Lipotoxicity. 2017;960. Tersedia dari: http://link.springer. com/10.1007/978-3-319-48382-5

6. Bessy Sitorus P. Peranan olahraga dalam meningkatkan kesehatan. J Pengabdi Kpd Masy. 2015;21:65-72.

7. Muwakhidah. Dian Tri H. Faktor Resiko yang Berhubungan dengan Obesitas pada Remaja. J Kesehat. 2008;1:133-40.

8. Fen Tih -, Pramono H, Hasianna ST, Naryanto ET, Haryono AG, Rachman O. Efek Konsumsi Air Kelapa (Cocos Nucifera) terhadap Ketahanan Berolahraga Selama Latihan Lari pada Laki-laki Dewasa Bukan Atlet. Glob Med Heal Commun. 2017;5(1):33.

9. Prasetyo Y. Kesadaran Masyarakat Berolahraga untuk Peningkatan Kesehatan dan Pembangunan Nasional. Medikora [Internet]. 2013;VOL.XI:219-28. Tersedia dari: https://journal.uny.ac.id/index.php/ medikora/article/downlo ad/2819/2344

10. Dylan Trotsek. Upaya bersepeda sebagai moda transportasi serta gaya hidup baru menjaga kebugaran jasmani. J Chem Inf Model. 2017;110(9):1689-99.

11. Burns PB, Rohrich RJ, Chung KC. The levels of evidence and their role in evidencebased medicine. Plast Reconstr Surg. 2011;128(1):305-10.

12. Julian V, Thivel D, Miguet M, Pereira B, Costes $\mathrm{F}$, Coudeyre E, et al. Eccentric cycling is more efficient in reducing fat mass than concentric cycling in adolescents with obesity. Scand J Med Sci Sport. 2019;29(1):4-15.

13. Bernstein R, Schneider R, Welch W, Dressel A, DeNomie M, Kusch J, et al. Biking for health: Results of a pilot randomized controlled trial examining the impact of a bicycling intervention on lower-income adults. Wis Med J. 2017;116(3):154-60.

14. Ratajczak M, Skrypnik D, Krutki P, Karolkiewicz J. Effects of an indoor cycling program on cardiometabolic factors in women with obesity vs. Normal body weight. Int $\mathrm{J}$ Environ Res Public Health. 2020;17(23):1-14.

15. Fedak KM, Bernal A, Capshaw ZA, Gross S. Applying the Bradford Hill criteria in the 21st century: how data integration has changed causal inference in molecular epidemiology. Emerg Themes Epidemiol. 2015;1-9. 